\title{
Somalia's threatened forests
}

\author{
Jane Madgwick
}

In 1986 the FFPS contributed $£ 750$ from its Oryx $100 \%$ Fund towards a study of riparian forest in Somalia. Only small fragments remain. The local and national importance of these forests demands that urgent action is taken to conserve them, as the author explains.

Tropical floodplain forest is one of the most vulnerable and threatened habitats in East Africa. In arid and semi-arid regions, these narrow strips of evergreen vegetation form a major link between savannah woodland and tropical lowland rain forest (Hughes, 1984). Compared with the surrounding woodland and bush these forests are floristically rich and are notable for their diversity of specialized birds and mammals (Andrews et al., 1975; UCL/TDRI, 1984; Madgwick et al., 1988). For these reasons, in recent years much attention has been focused on the conservation of representative areas of floodplain forest.

The floodplain forest in Somalia is the northernmost outlier of moist lowland forest in coastal East Africa (Figure 1). It is therefore of particular scientific interest. However, until 1986 there had been no systematic biological survey and the extent and composition of the remaining forest was unknown. Recent surveys have revealed that only a few hundred hectares remain intact in the whole of Somalia.

Forest once clothed the floodplains of the two perennial rivers in Somalia, the Jubba and Shabeelle (Pichi-Sermolli, 1957). Virtually all the forest that once occurred along the Shabeelle has been cleared (Douthwaite, 1987) although a small patch has been set aside as a reserve at $\mathrm{Bal}$ cad, managed by the Somali Ecological Society. Aerial photographs of 1960,1983/4 and 1987 show a drastic acceleration in forest clearance in the Jubba Valley (Deshmukh, 1987 and Table 1). Clearance for cultivation has been encouraged 94 by irrigation and drainage schemes in the upper and lower reaches of the valley (Saacow, Jilib and Jamaame Districts). Only the poorly accessible Middle Jubba (Bu'aale District) with predominantly saline, alkaline, impermeable soils, has retained significant areas of relict floodplain forest.

Field visits to the Jubba Valley have found only small patches of intact floodplain forest. A ground truth study of forest areas identified from the 1983/4 aerial photographs was carried out in 1986 by the Somalia Research Project (Madgwick et al., 1988). Large sections were found to have been recently cleared and burnt. Much of the rest was severely degraded through small-scale clearance for timber, fuel and grazing. The areas cleared of forest that have been examined by the Jubba Environmental and Socioeconomic Survey (JESS) and the Somalia Research Project, do not support regenerating forest species. Only two sizeable remnants of

Table 1. Extent of forest in the Jubba Valley in 1960, 1983/84 and 1987

\begin{tabular}{llll}
\hline & $\begin{array}{l}1960 \\
\text { ha(no. patches) }\end{array}$ & $\begin{array}{l}1983 / 4 \\
\text { ha (no. patches) }\end{array}$ & $\begin{array}{l}1987 \\
\text { ha (no. patches) }\end{array}$ \\
\hline $\begin{array}{l}\text { Bu'aale } \\
\text { to Fanoole }\end{array}$ & $1361(18)$ & $505(9)$ \\
$\begin{array}{l}\text { Jubba } 9346(84) \\
\text { Valley }\end{array}$ & $2611(44)$ & $897(21)$
\end{tabular}

The figures are estimates from aerial photographs. Source: Deshmukh, 1987. 
forest remain at Shoonto and Barako Madow (Figure 2). These reserves include approximately 350 ha of forest; about 40 per cent of the remaining forest vegetation in the whole river valley (Deshmukh, 1987).

Multi-layered, evergreen forest occurs in strips several hundred metres wide along the river levees, sustained by groundwater seepage and flooding. The forest is distinctive in composition and structure from woodland and bush, which are nested in sequence around the forest and are consequently less influenced by the river (Figure 2). A complex mosaic of vegetation types normally exists within the floodplain, the compo-

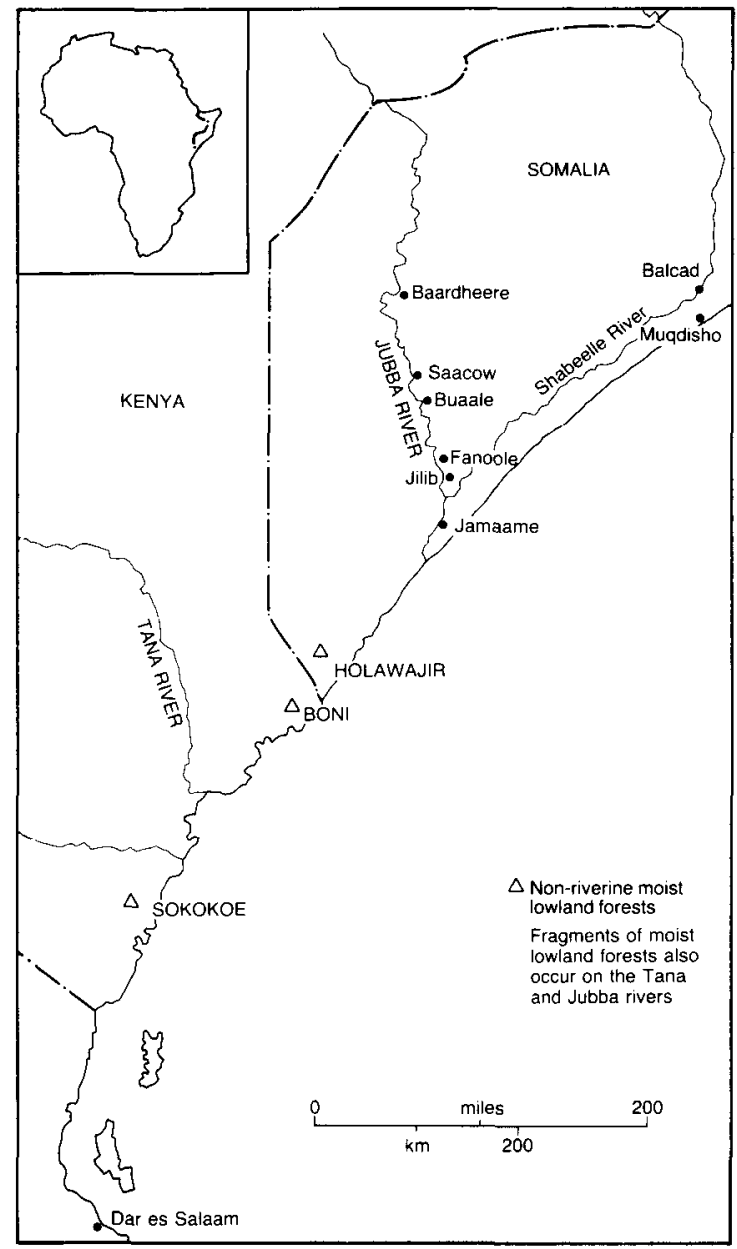

Figure 1. Distribution of moist lowland coastal forest in East Africa, showing places mentioned in the text. sition of any part probably depending on the timing and duration of past flooding, groundwater seepage and the types of sediments laid down. The river bursts its banks on average every other year and a sustained flood occurs about once every five years (LRDC, 1985), so the river constantly shifts its course through the erosion and deposition of sediments.

The richest forest grows on levees at the river edge (Figure 3). Fifty species of trees and shrubs are characteristic of the levee forest, and 12 of the tall, evergreen trees are restricted to the immediate river edge. The largest trees attain about $30 \mathrm{~m}$ and many have large buttresses. These include a spectacular strangling fig, Ficus scassellatii, and an ebony, Diospyros comii. There is a dense midstorey of tall shrubs, often with impenetrable liana thickets. Small shrubs and herbs are sparse near the river and the ground is covered with leaf litter and dead wood. Seedlings are abundant here and it appears that regeneration of many of the important canopy species is restricted to this seasonally inundated zone.

Further from the river, silt and clay are deposited; gullies and river debris are evidence of flooding. Here the canopy is more open and fewer species of tall trees occur. Large-crowned Acacias are frequent, the shrub layer is dense and herbaceous vegetation is limited to open glades, often edged with Sansevieria thickets.

Open, deciduous woodland abuts the evergreen forest and gives way to bushland at the edge of the floodplain. The woodland overstorey is diverse; trees and shrubs include Dobera loranthifolia and Balanites aegyptica. There is a continuous understorey of perennial grass. Intermediate types of vegetation often occur at the forest-woodland interface. Here, the doum palm, Hyphaene sp., and Newtonia erlangeri are frequent.

These last blocks of floodplain forest along the Jubba are home to a spectacular range of birds. Many of the species recorded are very rare and have an extremely localized distribution within Somalia. Indeed, it seems likely that as many as 20 bird species, which are dependent on the riverine forest, could be lost from the country if the remaining forest is cleared or degraded. None of these birds survive in degraded forest or 


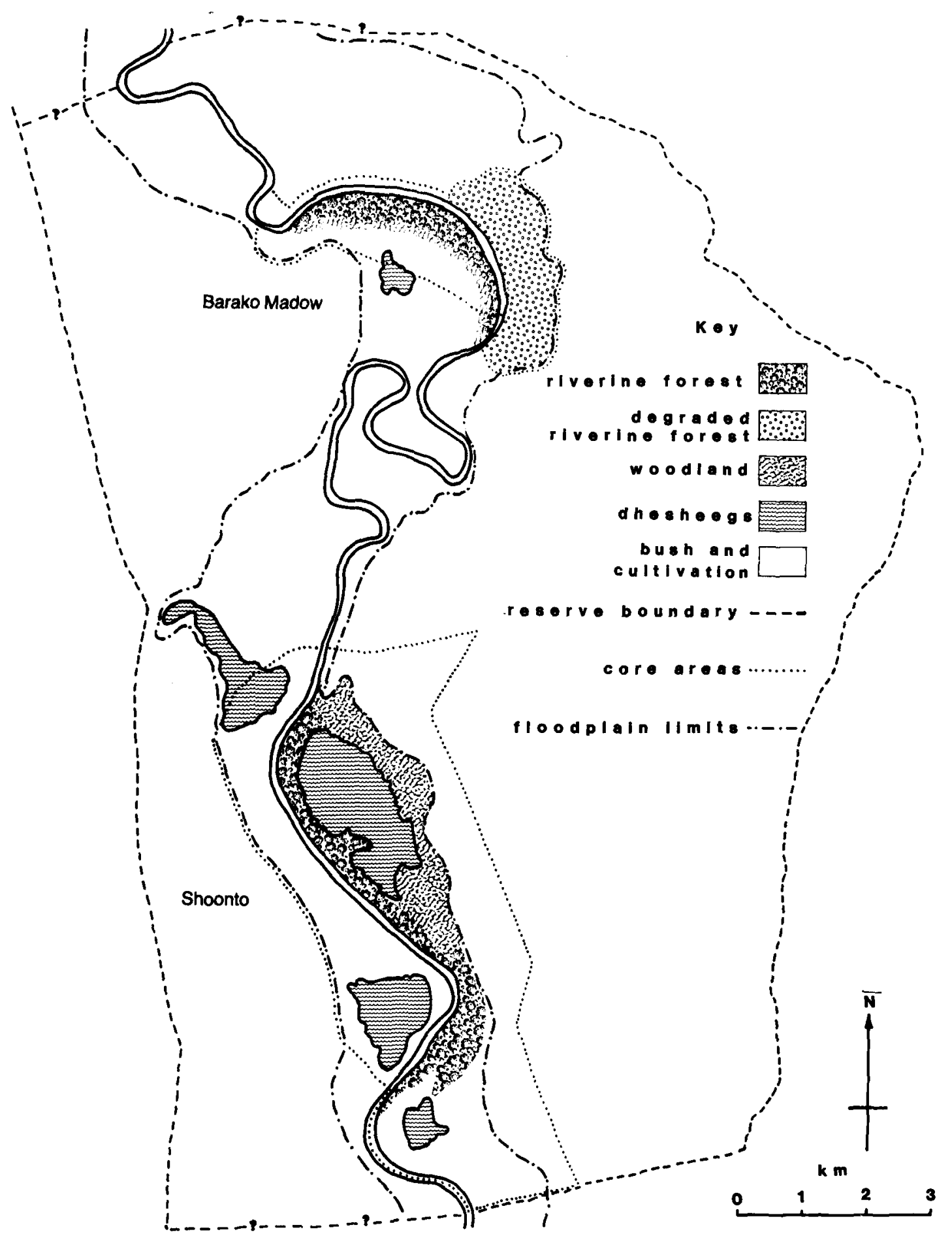

Figure 2. Vegetation types and physiography in the Middle Jubba Valley showing the proposed Wildlife Reserve boundary and the extent of core forest areas. 
the surrounding woodland and bush and most have limited powers of dispersal (Wood, in press). Many, such as the magnificent Pel's fishing owl Scotopelia peli and the little yellow flycatcher Erythrocercus holochlorus, are rare in East Africa. Some species, which feed in the upper canopy of the forest or on aerial insects, are threatened by plans to control tsetse-fly with insecticidal sprays along the whole river valley (Douthwaite, 1985).

During a detailed study of the forest in the dry season of 1986, 32 species of mammal were recorded in the two remaining forest blocks (Varty, in press). A number of the large mammals recorded there, such as the leopard Panthera pardus, are rare in Somalia. Others, such as the blue monkey Cercopithecus mitis are restricted to riverine forest. A variety of bats and rodents were found. The presence of the bats Pipistrellus eisentrauti and Nycteris parisii is of particular

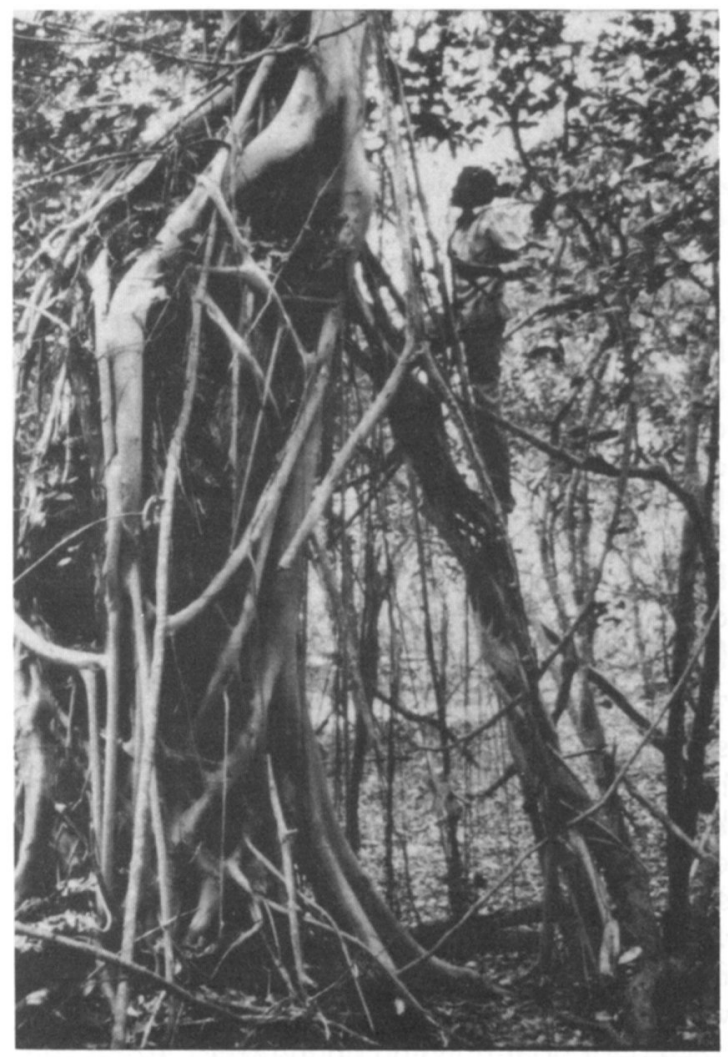

A strangling fig, Ficus scassellatii (Jane Madgwick). note, since both are internationally rare. Little is known at present about the detailed roles of mammals in the ecology of the forests, but many of the trees rely on pollination by bats, and blue monkeys, baboons Papio cyanocephalus, bush squirrels Paraxerus ochraceus and fruit bats Epomophorus wahlbergi play an important role in the dispersal of fruits and seeds.

A variety of large mammals use the forest during the dry season when they come for food, water and shade. Very few elephants Loxodonta africana now survive in southern Somalia, but they would have played an important part in the ecology of the forests as they fed on the fruits, stems, leaves, bark and roots of a variety of trees. African buffalo Syncerus caffer, hippopotamus Hippopotamus amphibius and waterbuck Kobus ellipsiprymnus are still frequently seen in the remaining blocks of forest. Others, such as gemsbok Oryx gazella and lesser kudu

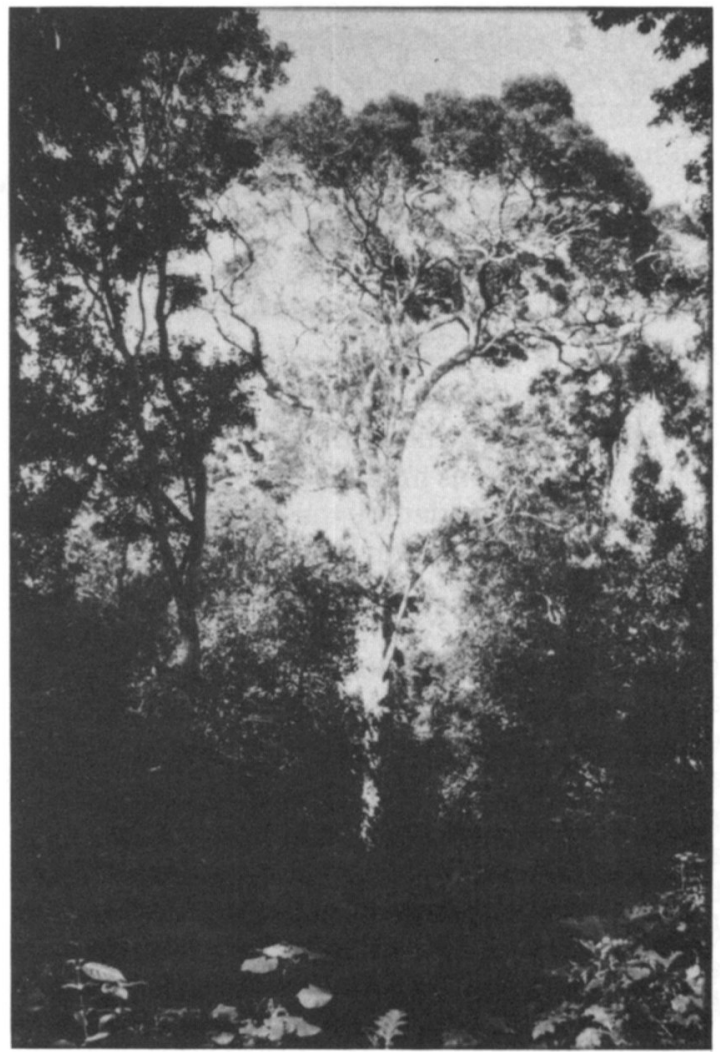

Seedlings of forest trees were plentiful in seasonally inundated zones (Jane Madgwick). 

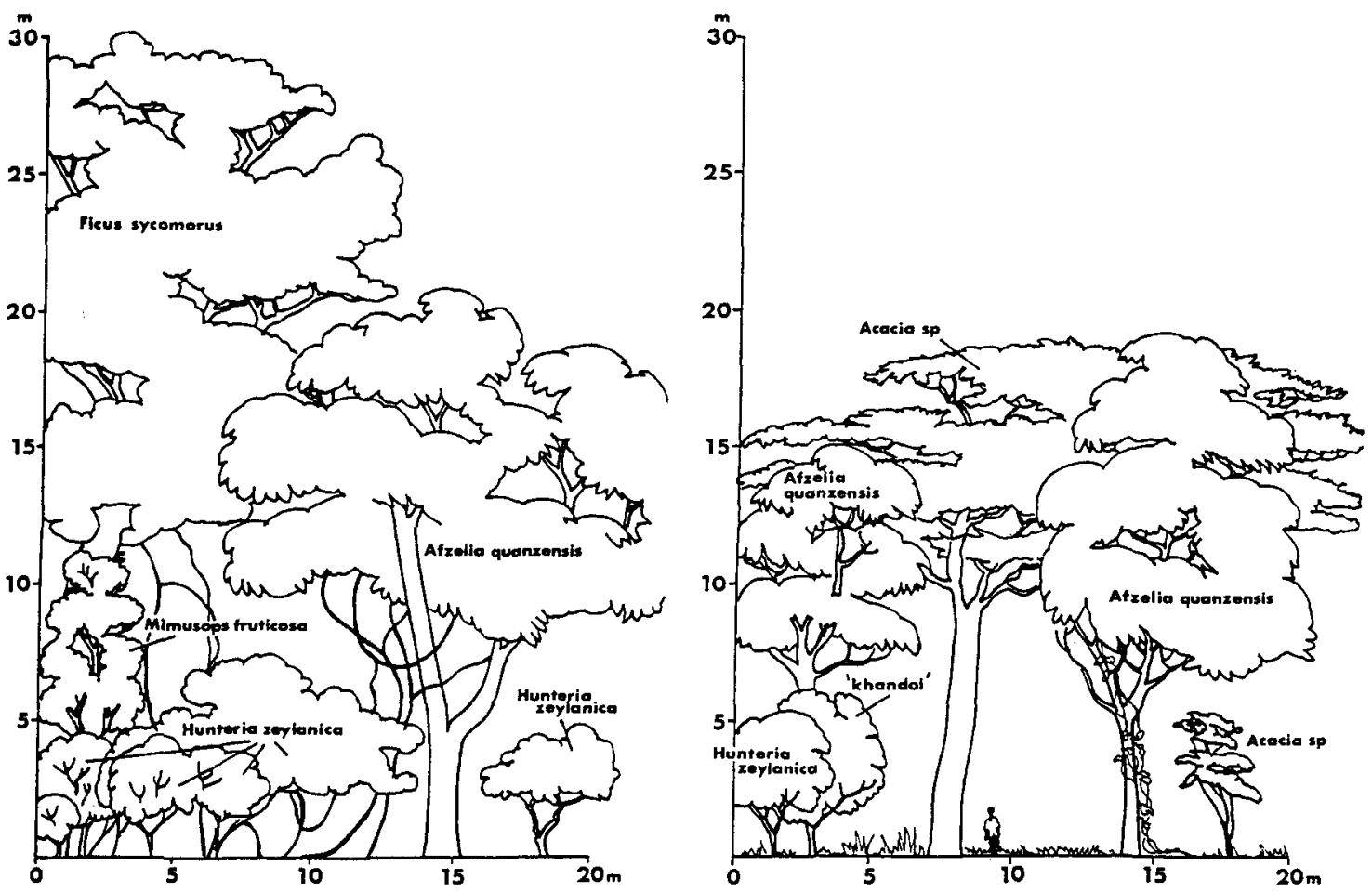

Figure 3. Section diagrams showing the structure of vegetation within sample plots at different positions on the floodplain: river edge; mid-levee and forest edge/woodland (from left to right).

Tragelaphus imberbis are occasional visitors.

Many of the larger animals travel between the river and the marshes bordering temporary, shallow lakes (locally called dhesheegs). These are natural depressions in the clay floodplain, which are seasonally flooded by the river and may also be fed by groundwater flow and run-off. The larger and deeper dhesheegs never dry out, while the water evaporates completely from others within 3-5 months. A large dhesheeg adjacent to the forest at Shoonto had been left uncultivated for over 30 years and here a marsh and low thicket fringe the forest edge. Hippopotamus and crocodile Crocodylus nilotica are abundant in the dhesheeg area, along with a tremendous variety of birds, including pelicans, Pelecanus onocrotalus and $P$. rufescens, fisheagles Haliaeetus vocifer and yellow-billed storks Mycteria ibis.

Most of the dhesheegs in the Middle Jubba are cultivated. Planting starts from the edge of the 98 dhesheeg and follows the shrinking water-level. Maize, sesame, beans and tobacco are the main crops. Often, excessive flooding washes out the crops and nearby villages, smothering the dhesheegs with fresh deposits. However, where forest clothes the river levees, it stabilizes them and so reduces scouring and erosion during floods. In this way, forest prevents dhesheeg crops and nearby villages from being destroyed (Brunken and Haupt, 1986).

The forests have many other direct uses for smallholder farmers in the Middle Jubba. They have played a vital role in the development of the local economy and culture. Wood is used for construction of huts, doors, tables, canoes and sesame presses, as well as for charcoal and firewood. Some of the riverine species are prized for their long, straight boles of termite-resistant wood and much has been commercially extracted for boat-building on the coast. Rope and fibres are made from certain lianas and Sansevieria, while other herbs, barks and roots are

Oryx Vol 23 No 2, April 1989 


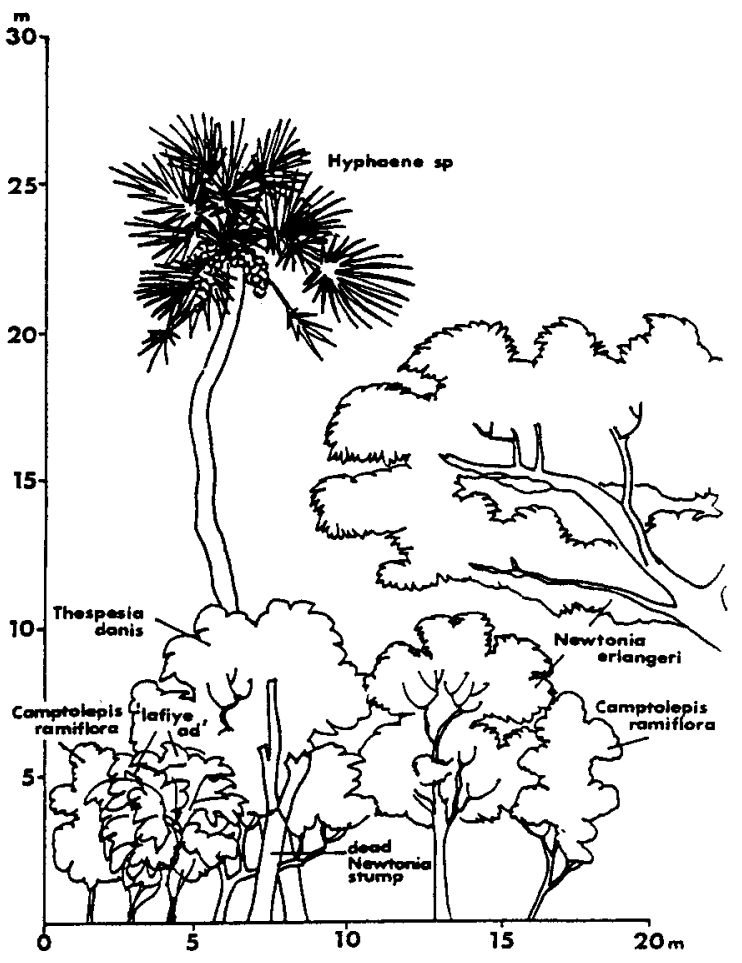

useful for dyes, glues and poisons. Forest plants are also put to an astounding variety of medicinal uses.

The forest is a source of food for the villagers. Hunting is illegal in Somalia, but much of the precious game meat is still derived from the forest. Honey, from forest bees, also provides the villagers with income. It is either taken from natural tree-hives in the forest, or cultivated in hollowed-out palm logs, placed in the dheydhey tree Newtonia erlangeri, on the forest edge. Fruits, such as figs, are seasonally abundant.

The future of the last stretches of riverine forest in Somalia depends on whether urgent action is taken by the Government. At present rates of loss, the forest will be destroyed in a couple of years. The future looks gloomy but some hope for its conservation may lie within the plans for agricultural development of the valley, now centrally co-ordinated by the Ministry for Jubba Valley Development.
Further development of agriculture within the valley depends on the regulation of river flow by a dam, currently being constructed near Baardheere. The dam is expected to be operable by 1993. Studies carried out in the riverine forest along the Tana river in Kenya (Hughes, 1984) indicate that the reduction in flooding caused by the dam may result in the disappearance of some tree species in the forest due to lack of regeneration. Roughly 200,000 ha of the floodplain will be irrigated for farming. Only 10 per cent of this land is currently cropped. The full environmental impact of this scheme has yet to be evaluated, but no plans have yet been included to support traditional subsistence farming in the dhesheegs.

The valley includes land of varying quality for irrigated agriculture but the Middle Jubba is notorious for having the poorest soils. This has been confirmed by recent soil surveys undertaken by USAID (United States Agency for International Development) in its environmental appraisal of the dam project. Extensive sections of black cotton soils have also made access impossible through the Middle Jubba twice a year, after the rains. This area is therefore of the lowest priority for irrigation.

The Middle Jubba has been identified as the area of greatest wildlife interest in the valley. The importance of conserving the forest in this area was highlighted in wildlife and land-use studies carried out by Funaioli and Simonetta (1966), Abel and Kille (1975) and Technital (1975). Since then proposals have been put forward for the establishment of wildlife reserves in the Middle Jubba by Simonetta and Simonetta (1983) and Madgwick et al. (1988).

Both remaining blocks of forest at Shoonto and Barako Madow are already official Forest Reserves under the control of the government National Range Agency (NRA). Legally, no one may use any forest products, yet the boundaries have not been established and the NRA wildlife guards are powerless to protect the forest without more local support. As in other 'reserves' in Somalia, destruction and degradation of the natural resource continues unchecked. Since the research project in 1986, 5 ha of Barako Madow have been cleared and the dhesheeg at Shoonto has been cultivated. Other fragments of forest 
along the river have been burnt or felled in anticipation of the irrigation schemes and as a followup to land registration.

From the beginning of planning, the establishment of wildlife reserves and corridors has been foreseen within the Master Plan for Jubba Valley Development. The Overseas Development Administration (LRDC, 1985) has stressed the need for effective forest reserves in the Middle Jubba area. But it is only recently that USAID, the Minister of Jubba Valley Development and the NRA have backed proposals to make Shoonto and Barako Madow functioning nature reserves. An outline management plan for a wildlife reserve has been prepared (Madgwick et al., 1988) and financial and technical support is now being sought by the Somali Ecological Society, which is steering the project. It is intended to protect the existing forest from further degradation within core areas of the reserve. Forest extension services should then encourage the re-establishment of forest along the river levees and the restoration of some of the degraded forest areas to a more natural state.

Long-term forest conservation will depend on the adoption of a conservation plan for the whole floodplain, worked out with village elders and endorsed by the District Government officers. This plan should consider the sustainable use of the area by villagers and so include measures for securing local land tenure, health facilities and income. Some technical assistance may be needed to manage natural foods such as fish and honey, which could improve diet and boost local income. The future use of fuelwood must be taken into account and villagers may need to adopt different, more efficient methods of cooking. Consequently, although urgent measures are needed in the short term to save the remaining forest, detailed plans for the future use of the surrounding areas must evolve to ensure its survival in the long term. If this project is successful, it will strengthen the work of the Somali Ecological Society and lead to the effective conservation of representative areas of other wildlife habitats in Somalia.

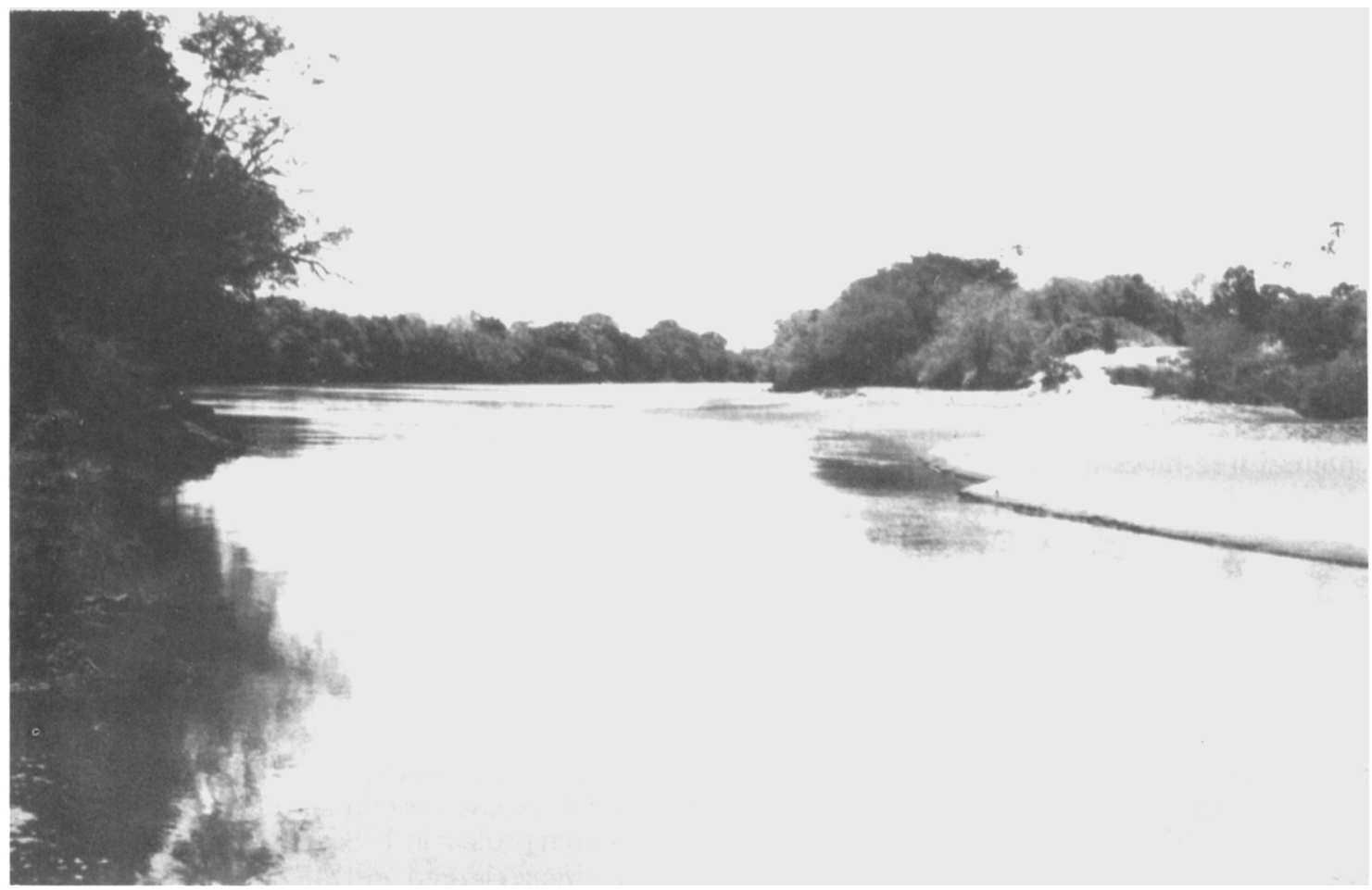




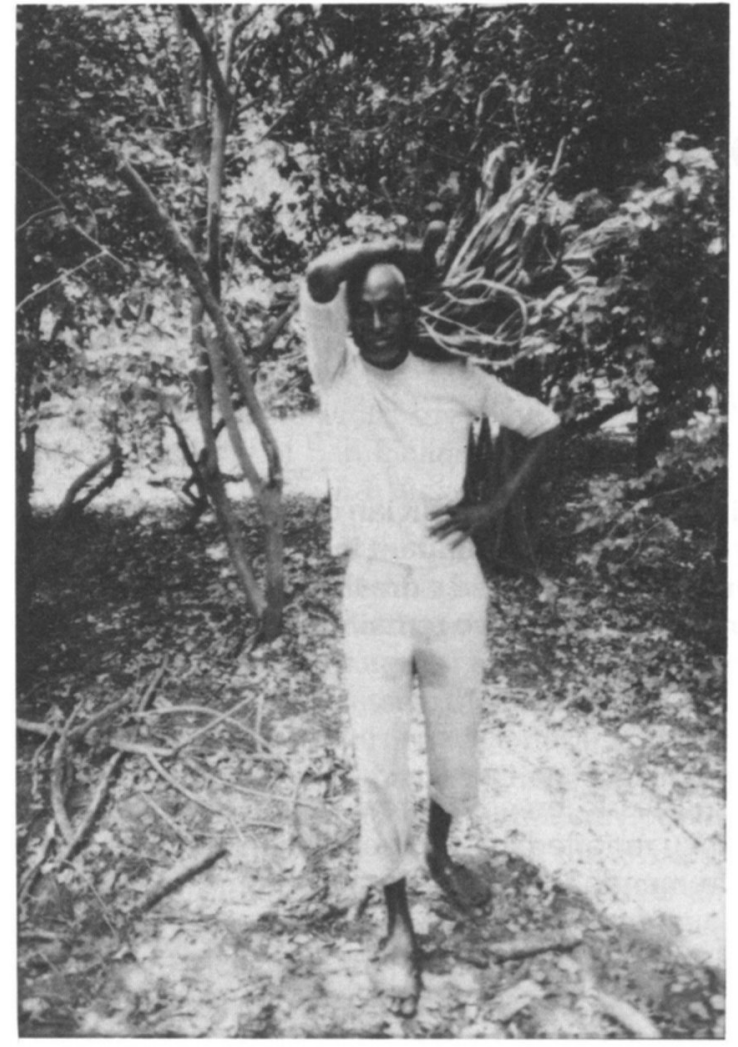

Certain species of lianes that occur only in the floodplain forests are cut for use in the construction of village huts (Jane Madgwick).

\section{Acknowledgments}

The Somalia Research Project team members are: Jane Madgwick, Brian Wood, Nigel Varty and Michael Maunder. We wish to thank the National Range Agency of Somalia for their co-operation and assistance. We are particularly grateful to Afgooye Forestry and Wildlife Training Centre (now the Institute of Forestry, Range and Wildlife), the Somali Ecological Society and the British Embassy, Somalia, for practical assistance with the project. Many thanks to all sponsors of the SRP and especially the Royal Society, British Ecological Society, Royal Geographical Society, University of London, Fauna and Flora Preservation Society, Royal Botanic Gardens Kew, Overseas Development Administration, the Associates in Rural Development and United States Agency for International Development.

Copies of the Final Report of the Somalia Research Project (172pp) are available at $\{5 /$ copy from SRP, Ecology and Conservation Unit, University College London, Gower Street, London WC1E 6BT.

\section{References}

Abel, N.O.J. and Kille, M.E. 1975. Conservation and exploitation of the wildlife of south-eastern Somalia. Field document No. 5. UNDP, FAO, Mogadishu.

Andrews, P., Groves, C.P. and Home, J.F.M. 1975. Ecology of the Lower Tana floodplain (Kenya). J. E. Afr. Nat. Hist. Soc. and Nat. Mus. 151, 1-31.

Brunken, $H$. and Haupt W. 1986. The importance of the Jubba Valley for the development of agriculture in Somalia. In Agriculture in the Winds of Change leds. Conze and Labahn). Epiverlag Gmbtl, SaarbruckenSchafbrücke, Germany.

Deshmukh, I. 1987. Riverine forests in the Jubba Valley: Issues and recommendations for conservation. JESS Interim Report. Unpublished.

Douthwaite, R.J. 1985. Environmental Aspects of Tsetse Fly Eradication in Somalia. Tropical Development and Research Institute, London.

Douthwaite, R.J. 1987. Lowland forest resources and their conservation in southern Somalia. Environmental Conservation 14, 29-35.

Funaioli, U. and Simonetta, A.M. 1966. The mammalian fauna of the Somali Republic. Status and conservation problems. Monit. Zool. Ital., LXXIV, 285-347.

Hughes, F.M.R. 1984. A comment on the impact of development schemes on the floodplain forests of the Tana river Kenya. The Geographical Joumal, 150, 230-244.

LRDC. 1985. Land Use in Tsetse Affected Areas of Southem Somalia (ed. C.R.C. Hendy). Prepared for NTTCP by LRDC (Land Resources Development Centre), Overseas Development Administration.

Madgwick, J., Maunder, M., Varty, N. and Wood, B. 1988. An Ecological Study of the Remaining Areas of Riverine Forest in the Jubba Valley, Southern Somalia; Final Report (ed. J. Madgwick). Somalia Research Project, University College London.

Pichi-Sermolli, R.E.G. 1957. Una Carta Geobotanica dell' Africa Orientale (Eritrea, Ethiopia, Somalia). Webbia, 13, 15-132.

Simonetta, A.M. and Simonetta, J. 1983. An Outline of the Status of the Somali Fauna and of its Conservation and Management Problems. Centro di Faunistica ed Ecologia Tropicale.

Technital. 1975. Juba River Development Study, Technical SpA, Rome.

UCL/TDRI. 1984. Report on the Species of Woody Plants and Vertebrates in Riverine and Coastal Forest Habitats of Southem Somalia, and the Lower Tana in Kenya (ed. A. Warren). Overseas Development Administration.

Varty, N. In press. Mammals and problems of their conservation in the riverine forests of the Jubba Valley, southern Somalia. Tropical Zoology.

Wood, B. In press. The bird community of floodplain forest in Somalia. In: Lavori della Societa Italiana di Biogeografia.

Jane Madgwick, Somalia Research Project, c/o Ecology and Conservation Unit, University College London, Gower Street, London WC1E 6BT, UK. 